\title{
АНАЛИЗ ФОРМИРОВАНИЯ РЕГИОНАЛЬНОГО БЮДЖЕТА
}

\author{
(c) 2018 Боташев Руслан Алибекович \\ Северо-Кавказская государственная академия \\ 369000, г. Черкесск, ул. Ставропольская, д. 36 \\ (c) 2018 Чотчаева Мадина Зулкарнаевна \\ кандидат экономических наук, доцент кафедры «Экономическая теория» \\ Северо-Кавказская государственная академия \\ 369000, г. Черкесск, ул. Ставропольская, д. 36 \\ E-mail: madinach@mail.ru
}

В статье проведен анализ процесса формирования регионального бюджета на примере Карачаево-Черкесской республики. Рассматривая вопрос формирования региональных бюджетов и распределения налогов между бюджетами разных уровней, можно отметить преобладание федеральных налогов по сравнению с местными, как по количеству, так и уровню налоговых платежей на протяжении всего развития и становления налоговой системы.

Ключевые слова: налоговые доходы, налоговое администрирование, региональный бюджет, Карачаево-Черкесская республика.

В настоящее время действующий порядок разграничения налоговых источников между звеньями бюджетной системы в России не в полной мере обеспечивает потребность региональных и местных бюджетов в собственных источниках доходов для осуществления отдельных расходных полномочий, что создает сложности при балансировании местных бюджетов и подтверждает необходимость усовершенствования налогового механизма.

Одним из путей достижения сбалансированности бюджета является рост его доходной части, в том числе и за счет увеличения налоговых доходов [1].

Немаловажным является дальнейшее совершенствование нормативно-правовой основы, регламентирующей процесс составления проекта доходной части государственного бюджета, соответственно доходной части бюджетов бюджетной системы страны [2].

Далее рассмотрим роль налоговых доходов в формировании республиканского бюджета на примере Карачаево-Черкесской республики (табл.1).

Из табл.1 видно, что на протяжении рассматриваемого периода темпы роста по налогам имеют положительный характер. В 2017 году отрицательная динамика наблюдается только по государственной пошлине. В целом прирост налогов, сборов, иных обязательных платежей в доходы консолидированного бюджета КЧР в
2017 г. составил 6,94\%. На протяжении рассматриваемого периода наблюдается положительная динамика по налогам, администрируемым в консолидированный бюджет КЧР. Данный показатель увеличился в абсолютном выражении на 1386491тыс.руб. Налоговые доходы бюджета КЧР в основном формируются за счет налога на прибыль и налогов на имущество. Большая часть положительной динамики по налоговым поступлениям в бюджет КЧР обеспечена отчислениями налога на прибыль. В 2016 г. прирост по налогу на прибыль составил 21,83\% (868451тыс. руб.), а в 2017 г.-4,64\% (224957тыс.руб.). Поступления по налогу на имущество также носят положительную динамику. Суммарно за рассматриваемый период бюджетные доходы по нему выросли на 225081тыс.руб. Значительно выросли налоговые поступления по специальным налоговым режимам - в 2016г прирост составил $2,69 \%$, а в $2017 г$ - уже $8,68 \%$.

За исследуемый период роль налоговых доходов в формировании доходной части республиканского бюджета несколько возросла (на $6,1 \%$ от общего объема). При этом, по нашему мнению, доля налоговых доходов в общем объеме доходов бюджета КЧР не является достаточной.

Недостаточность собственных источников финансирования делает бюджет КЧР зависимым от прочих, в том числе и безвозмездных поступлений из федерального бюджета РФ. 
Таблица 1. Поступления налогов и сборов в консолидированный бюджет КЧР за 2015 г.-2017 г.

\begin{tabular}{|l|c|c|c|c|c|}
\hline \multicolumn{1}{|c|}{ Показатели } & 2015 г., тыс. & $\begin{array}{c}2016 \text { г., тыс. } \\
\text { руб. }\end{array}$ & $\begin{array}{c}2017 \text { г., тыс. } \\
\text { руб. }\end{array}$ & \multicolumn{2}{|c|}{ Темпы прироста,\% } \\
\cline { 3 - 7 } & руб. & 2016 г. к & $\begin{array}{c}2017 \text { г. к } \\
2016 \text { г. }\end{array}$ \\
\hline Налоги на прибыль, доходы & 3977912 & 4846363 & 5071320 & 21,83 & 4,64 \\
\hline $\begin{array}{l}\text { Налоги на товары (работы, услуги), реализу- } \\
\text { емые на территории Российской Федерации }\end{array}$ & 23009 & 35079 & 39513 & 52,46 & 12,64 \\
\hline Налоги на имуществ & 1016383 & 1056751 & 1241464 & 3,97 & 17,48 \\
\hline $\begin{array}{l}\text { Налоги, сборы и регулярные платежи за } \\
\text { пользование природными ресурсами }\end{array}$ & 40934 & 41431 & 42169 & 1,21 & 1,78 \\
\hline Государственная пошлина & 39720 & 53396 & 49462 & 34,43 & $-7,37$ \\
\hline $\begin{array}{l}\text { Неналоговые доходы, администрируемые } \\
\text { налоговыми органами }\end{array}$ & 3337 & 2415 & 3851 & $-27,63$ & 59,46 \\
\hline $\begin{array}{l}\text { Платежи при пользовании природными } \\
\text { ресурсами }\end{array}$ & 41 & 31 & 45 & $-24,39$ & 45,16 \\
\hline Штрафы, санкции, возмещение ущерба & 3296 & 2384 & 3806 & $-27,67$ & 59,65 \\
\hline Налоги на совокупный доход & 345145 & 354417 & 385183 & 2,69 & 8,68 \\
\hline $\begin{array}{l}\text { Поступило налогов, сборов, иных обязатель- } \\
\text { ных платежей в доходы консолидированно- } \\
\text { го бюджета Кчр }\end{array}$ & 5446232 & 6389285 & 6832723 & 17,32 & 6,94 \\
\hline
\end{tabular}

Важнейшим этапом налогового процесса является исполнение бюджета, который предусматривает обеспечение полного и своевременного поступления всех предусмотренных по бюджету доходов, своевременное и полное финансирование всех запланированных бюджетных расходов. Рассмотрим показатели контрольной работы по администрированию налоговых поступлений (табл.2).

Необходимо отметить, что количество проведенных камеральных проверок увеличилась на $17,1 \%$ в 2016 г. и на $24,96 \%$ в 2017 г., количе- ство выездных проверок сократилось с 189 единиц до 95единиц в 2107 г. Однако результативность выездных проверок значительно выше. Так в 2017 г. она составила 100\%. Несмотря на то, что налоговые доходы бюджета КЧР в основном формируются за счет налога на прибыль, по ним наблюдается недостаточная собираемость (табл.3).

По состоянию на 01.01.2018 г. общая задолженность по налогам и сборам в КЧР в консолидированный бюджет составляет 2929201 тыс. руб., это на 62,2\% больше, чем на 01.01.2017 г. Из

Таблица 2. Показатели контрольной работы по УФНС России по КЧР за 2015-2017 гг.

\begin{tabular}{|c|c|c|c|c|c|c|c|}
\hline \multirow{2}{*}{ Показатели } & \multirow{2}{*}{2015 г. } & \multirow{2}{*}{2016 г. } & \multirow{2}{*}{2017 г. } & \multicolumn{2}{|c|}{$\begin{array}{l}\text { Абсолютное } \\
\text { отклонение }\end{array}$} & \multicolumn{2}{|c|}{ Темпы роста,\% } \\
\hline & & & & $\begin{array}{l}2016 \text { г. к } \\
2015 \text { г. }\end{array}$ & $\begin{array}{l}2017 \text { г. к } \\
2016 \text { г. }\end{array}$ & $\begin{array}{l}2016 \text { г. к } \\
2015 \text { г. }\end{array}$ & $\begin{array}{l}2017 \text { г. к } \\
2016 \text { г. }\end{array}$ \\
\hline Камеральная налоговая проверка & 58579 & 68594 & 85718 & 10015 & 17124 & 117,10 & 124,96 \\
\hline $\begin{array}{l}\text { Дополнительно начислено платежей } \\
\text { (включая налоговые санкции и пени), } \\
\text { тыс. рублей }\end{array}$ & 38817 & 62410 & 57435 & 23593 & -4975 & 160,78 & 92,03 \\
\hline из них выявившие нарушения & 4835 & 5628 & 7595 & 793 & 1967 & 116,40 & 134,95 \\
\hline $\begin{array}{l}\text { Результативность камеральной нало- } \\
\text { говой проверки,\% }\end{array}$ & 8,25 & 8,20 & 8,86 & $-0,05$ & 0,66 & 99,41 & 107,99 \\
\hline Выездная налоговая проверка & 189 & 124 & 95 & -65 & -29 & 65,61 & 76,61 \\
\hline $\begin{array}{l}\text { Дополнительно начислено платежей } \\
\text { (включая налоговые санкции и пени), } \\
\text { тыс. рублей }\end{array}$ & 856901 & 173983 & 290305 & -682918 & 116322 & 20,30 & 166,86 \\
\hline из них выявившие нарушения & 187 & 123 & 95 & -64 & -28 & 65,78 & 77,24 \\
\hline $\begin{array}{l}\text { Результативность выездной налого- } \\
\text { вой проверки,\% }\end{array}$ & 98,94 & 99,19 & 100,00 & 0,25 & 0,81 & 100,25 & 100,81 \\
\hline
\end{tabular}


Таблица 3. Динамика налоговой задолженности УФНС России по КЧР за 2015-2017 годы, тыс. руб.

\begin{tabular}{|l|c|c|c|c|c|c|}
\hline \multicolumn{1}{|c|}{ Показатели } & & & \multicolumn{3}{|c|}{ Темпы роста,\% } \\
\cline { 5 - 8 } & 2015 г. & 2016 г. & 2017 г. & $\begin{array}{c}2016 \text { г. к } \\
2015 \text { г. }\end{array}$ & $\begin{array}{c}2017 \text { г. к } \\
2016 \text { г. }\end{array}$ & $\begin{array}{c}2017 \text { г. к } \\
2015 \text { г. }\end{array}$ \\
\hline Задолженность перед бюджетом по налогам и сборам & 2386858 & 1805663 & 2929201 & 75,6 & 162,2 & 122,7 \\
\hline $\begin{array}{l}\text { Задолженность по налогам и сборам не возможная к } \\
\text { взысканию }\end{array}$ & 30694 & 51572 & 35475 & 168 & 68,8 & 115,6 \\
\hline Урегулированная задолженность & 788355 & 347733 & 301325 & 44,1 & 86,8 & 38,2 \\
\hline
\end{tabular}

общей суммы задолженности перед бюджетом 1,21\% является не возможной к взысканию. Наличие столь значительной суммы задолженности по налогам и сборам в КЧР свидетельствует о несовершенной системе налогового администрирования и недостаточном уровне налоговой дисциплины налогоплательщиков.

В связи с уменьшением нормативов зачисления в бюджеты субъектов по налогу на прибыль организаций и акцизам на нефтепродукты, динамику объемов поступлений налоговых и неналоговых доходов с 01.01.2017 года можно рассматривать только в сопоставимом виде. При этом в соответствии с новыми нормами Бюджетного кодекса Российской Федерации дотация на выравнивание бюджетной обеспеченности предоставляется на условиях, отраженных в соответствующем соглашении, основным из которых является достижение запланированного темпа роста налоговых и неналоговых доходов по итогам финансового года.

В целях изыскания дополнительных поступлений в бюджет республики и обеспечения его сбалансированности 8 июня 2017 года Главой КЧР утвержден план по мобилизации доходов в бюджет КЧР, мероприятия которого охватывают большинство направлений роста собственных доходов, повышения налоговой дисциплины и легализации «теневого» бизнеса. Особое внимание уделяется повышению эффективности имущественного налогообложения и увеличению поступления имущественных налогов за счет вовлечения в налогообложение новых объектов недвижимости [3].

В предыдущие годы начата работа по актуализации налоговой базы по земельному налогу и имущественным платежам, созданию электронной системы похозяйственного учета муниципальных образований, проведению электронных сверок баз данных налоговых и регистрирующих органов с данными органов местного самоуправления. Взаимодействие регистрирующих органов с органами местного самоуправления по уточнению видов разрешенного использования и категорий земель дает положительные результаты, о чем свидетельствует низкий процент отсутствия кадастровой стоимости у земельных участков $(0,67 \%$ от общего количества земельных участков, содержащихся в ГКН).

Необходимо эффективней использовать электронный похозяйственный учет, выявлять недостающие данные, создавать актуальную базу данных о жителях поселений и их имуществе, систематизировать учет объектов налогообложения на территории поселений, определять реальный налоговый потенциал.

В целях повышения эффективности налогообложения имущества физических лиц, КЧР в числе первых 28 субъектов Российской Федерации с 1 января 2015 года ввела на своей территории налогообложение от кадастровой стоимости. По итогам первых начислений за 2015 год размер налога в целом по субъекту и по большинству населенных пунктов снизился, что обусловлено применением вычетов в размере 50 кв. м площади жилого дома, соизмеримым в небольших поселениях с общей площадью домовладений, а также корректировкой суммы налога на коэффициент 0,2 в первый налоговый период. В связи с этим с 01.01.2016 года ставка по жилым домам была повышена до 0,3\%.

С учетом применения повышенной ставки и корректировки суммы налога на коэффициент 0,4 во второй налоговый период, органам местного самоуправления необходимо провести анализ исчисленного налога и, в случае необходимости, принять решения о понижении ставки в отдельных поселениях.

Завершающим этапом по переходу к исчислению налогов на недвижимость исходя из кадастровой стоимости стало введение с 01.01.2017 года уплаты налога на имущество организаций в отношении отдельных объектов исходя из кадастровой стоимости в соответствии со ст. 378.2 Налогового кодекса. В соответствии с Законом 
КЧР от 30.11.2016 № 77-Р3 на 2017 год утвержден Перечень из 36 объектов делового, административного и коммерческого назначения, торговых объектов, объектов общественного питания и бытового обслуживания, площадью свыше 3000 кв. метров.

В соответствии со ст. 227.1 части второй Налогового кодекса РФ с 2017 года в КЧР установлен коэффициент, отражающий региональные особенности рынка труда, в размере, равном 1,6. Введение регионального коэффициента положительно отразилось на поступлениях налога на доходы физических лиц в бюджет КЧР. Количество выданных патентов за 2017 год увеличилось в сравнении с прошлым годом. Поступление налога на доходы физических лиц в виде фиксированных авансовых платежей с доходов, полученных физическими лицами, являющимися иностранными гражданами, осуществляющими трудовую деятельность по найму на основании патента, увеличилось более чем в 1,9 раза [3].

В целях сокращения задолженности и недоимки по платежам в республиканский бюджет необходимо продолжить целенаправленную работу с предприятиями - недоимщиками по платежам в бюджет республики по погашению задолженности, а также осуществлению мер принудительного взыскания задолженности путем обращения взыскания задолженности на имущество должников. Реализация высказанных мер способствовала бы наращиванию собственной доходной базы регионального бюджета КЧР.

\section{Библиографический список}

1. Меликян Л.А., Гурдзибеева А.А., Багиаев З.В. Воздействие налогового механизма на формирование регионального бюджета // Международный академический вестник. 2018. № 1-1 (21). С. 68-75.

2. Ташматова Р.Г. Роль налогового прогнозирования в формировании налоговых доходов бюджета// Экономика и бизнес: теория и практика. 2018. № 1. С. 79-82.

3. Основные направления налоговой политики Карачаево-Черкесской республики на 2018 год и на плановый период 2019 и 2020 годов- http://kchr.ru/left_menu/economy/finance/finance2/. 